\title{
THE USE OF GEOINFORMATION IN LAND ACQUISITION FOR ROAD DEVELOPMENTS
}

\author{
Jan Kazak, M.Sc. \\ Department of Spatial Economy \\ Wroctaw University of Environmental and Life Sciences \\ e-mail:jan.kazak@up.wroc.pl
}

\author{
Szymon Szewrański, D.Sc. \\ Department of Spatial Economy \\ Wroctaw University of Environmental and Life Sciences \\ e-mail: szymon.szewranski@up.wroc.pl
}

\begin{abstract}
The development of new areas is associated with costs that partly burden public budgets. One example of such costs is the necessity of purchasing land for the construction of public roads. Geoinformation can be used to forecast such costs.

In the era of transformation, the land administration system and transition from traditional (raster) data to an electronic (vector) version opens new possibilities for the use of geoinformation. Modern systems must satisfy certain requirements set out by the recipient as well as by legislation, on both the European and national level. They must also be powered by expertise gained in accordance with good practice. In this case, a property appraiser is the source of such information..

The study presents the possibility of using the CommunityViz system for forecasting the financial consequences of adopting the local plan for the area Jagodno II in Wroclaw. The paper also presents the possibility of using the results of the calculations during public consultations.
\end{abstract}

Keywords: land acquisition, road developments, geoinformation, CommunityViz.

JEL Classification: R28, R42, R48

Citation: Kazak J., Szewrański S., 2014, The use of geoinformation in issues of land acquisition for road developments, Real Estate Management and Valuation, vol. 22, no. 1, pp. 32-38.

DOI: $10.2478 /$ remav-2014-0004.

\section{Introduction}

The rationale for considerations taken in this work is a report on the financial effects of the space management system and the results of activities undertaken by the "Finance in the urbanization" research team. The article explores selected economic aspects of the Polish space management system, in particular the impact of planning decisions on the state of local government budgets. The system is based on the assumption that existing taxpayers should not be charged with the cost of settling new residents. However, the conclusions of the report show the income derived from the new urbanization to be disproportionate to the costs it generates, with the majority of these being connected with the implementation of road projects. The total amount of commune and city obligations resulting from the acquisition of land for public roads has been estimated at about 130 billion PLN on the national scale. The average rate of growth of these obligations for the years 2003-2010 is approximately 50 million PLN per day (OLBRYSZ and KOZIŃSKI 2011).

The report also draws attention to the minimal level of social knowledge and interest concerning the issue of the planning decisions made. However, the growing commitment of communes may result in taxpayers acquiring some knowledge on the subject, which in turn could lead to social 
conflicts (OLBRYSZ and KOZIŃSKI 2011). A solution to this problem could be to intensify efforts to create a multi-purpose information systems focused on the social approach to the management and development of the real estate market. This model is often adopted by developed countries and presents a new approach to the problem of creating a real estate market. It is in contradiction with the system used in many developing countries, which is confined within rigid formal and official frames (ŹRÓBEK and ŹRÓBEK 2008).

The issue of whether to use geoinformation systems is an important aspect of land management. It is also a topic that causes a lot of controversy. This includes the mutual relationship between property rights and the implementation of public purpose. A property holder, for example, can be deprived of this right and get the adequate compensation if planning instruments predict a public purpose in the given area (ŹRÓBEK et al. 2012). Acquisitioning land for the construction of roads may be done by negotiating or by means of an administrative decision made by a competent authority. During such negotiations, the authority may offer the land owner a substitute piece of real estate (SIKORA 2012). However, this is where the property owners' attitudes come into play. According to SzabatPręcikowska (2012), they are reluctant to give up their property for public purposes. Sometimes, this is related to the problem of the rational management of the remaining space around the existing development. The acquisition of land for public development is often a debatable and time-consuming process. Therefore, the changes that have been brought on by law since 16 December 2006 concerning special rules for the preparation and implementation of public road development should be assessed positively, as they speed up the whole process (ŹROBEK and WALACIK 2008).

Considerations within the paper concern the possibility of using geoinformation in land purchases for road investments. The study consists of an analysis of records on planning and the ownership of real estate, and the resulting need to acquire land for public purposes. An attempt has been made to carry out such calculations by using geoinformation. Attention has been paid to the possibility of visualizing the values obtained so that they can be used in the decision-making process, such as during public consultations regarding the local plan. These analyses were carried out using the CommunityViz system.

\section{Land administration system}

\subsection{The concept of the system}

When defining the concept of a land administration system, we must first specify the recipient who it serves. There will be differences between systems constructed for public administration, aiming to improve the functioning of the state at each of its levels, and those constructed for society, used as a platform for communication between the administration and the citizens. This does not mean that the improvement of administration cannot be combined with increased social participation. However, the main goal should be to raise awareness of the real estate market so that people can make rational decisions, based on their knowledge of the current economic situation.

While seeking guidance in describing the features of the land administration system, it is worth noting the documents issued by the Economic Commission for Europe of the United Nations (UNECE). These are the LAND ADMINISTRATION GUIDELINES WITH SPECIAL REFERENCE TO COUNTRIES IN TRANSITION issued in 1996 and LAND ADMINISTRATION IN THE UNECE REGION, DEVELOPMENT TRENDS AND MAIN PRINCIPLES issued in 2005. The four basic functions of real estate management can be found in the conclusions of these documents, i.e.: legal, fiscal, regulatory, and information management. While the first three functions are, in principle, defined in certain organizational frameworks in most countries, the informative function, or information management is not implemented everywhere. This function should, therefore, be a point of reference in the development of a real estate management system, acting as a platform for communication with the citizens. The document also focuses on the benefits of a well-functioning land administration system.

It is also important for the framework of the land administration system to be standarized, and provide a comprehensive approach in order to be able to perform various administrative tasks (STEUDLER et al., 2004). DALE (2000) sees the property management system as a multidisciplinary forum where issues regarding real estate can be analyzed from many perspectives, beyond that of a public service mission. While creating a land administration system, it is worth using experience from the functioning of real estate management counseling, which is implemented in some countries. The situation observed in England shows that this area may be subject to the processes of privatization, 
and that this can lead to the self-organization of systems managed by independent organizations. This, in turn, can lead to creative diversity and developing new solutions resulting from the local needs (KLERKX and PROCTOR 2013).

\subsection{Data availability}

The correct functioning of a land administration system is dependent on the data that are used in it. When speaking about data, we should refer to the Directive (2007/2/EC) of the European Parliament of 14 March 2007 establishing an Infrastructure for Spatial Information in the European Community (INSPIRE). The general principles of how this infrastructure operates involve:

1) one-time data gathering, their correct and effective storage and management performed by the appointed services;

2) securing the spatial continuity of the data so that they can be obtained from various sources and made available to different users for different purposes;

3) storage of geodata at the appropriate level of public administration, and making them available to other users at all levels;

4) ensuring universal access to spatial data needed for management at all levels of government;

5) ensuring that the public is informed about the availability of spatial data and the conditions of its use.

The directive makes clear the need to implement technological changes and specifies the electronic format as a valid format of exchanging data in the art. 4 .

Providing the public with access to geoinformation is implemented not only by the INSPIRE directive, but also by: the created technical infrastructure (SDI - Spatial Data Infrastructure), the adoption of standards (such as ISO - International Organization for Standardization), reaching agreements between institutions, or harmonizing the structure and quality of spatial data (WĘŻYK and WAŃCZYK 2008). The Act of 4 March 2010 on the Spatial Information Infrastructure (i.e., Acts. Laws of 2010 No. 76, item. 489, with further amendments), is the basis for transposing provisions of the INSPIRE directive onto the national law. Chapter 4 on spatial data services clearly defines the operations which spatial data can be subjected to. These include: searching, browsing (at a minimum: displaying, navigating, zooming in and out, moving or overlaying viewable files and displaying explanations of symbols and the content of metadata), downloading, copying or directly accessing files, and transforming the data in order to achieve the interoperability of collections and services, and to enable the launch of spatial data.

These guidelines are implemented in various services at different levels, such as: geoportal.gov.pl at the national level, wrosip.pl - at the NUTS 4 level, geoportal.wroclaw.pl - at the city level (NUTS 4), and zakrzowek.ispik.eu - at the commune level (NUTS 5). However, not every site has the same generic data. When comparing the services of Wroclaw county (NUTS 4) and the city of Wroclaw, in addition to common elements, such as a basic map, local spatial plans, and education, one can also find several differences, such as: offers to sell real estate and a description of land use and arable land classifications (in the service of Wroclaw county), or an acoustic map and housing program (in the city of Wroclaw service).

However, not all units have implemented such systems, which can result in certain problems. The changes leading up to the unification of the system can be positively evaluated but, at the same time, it is necessary to seek further applications and possible uses of these systems and the data they contain in the daily functioning of the economy of the country.

\section{Geoinformation in estimating the costs of land acquisition}

The study attempted to confront the need for information, which is possible to obtain from spatial data, and software functionality facilitating spatial analysis and the clear visualization of results. The research problem was, at this point, to estimate the community obligations arising from the need to acquire land for the construction of public roads as the result of a local plan being passed. For this purpose, the authors used the Wrocław City Council resolution of 13 September 2007 on adopting the local spatial plan for the area of Jagodno II in Wroclaw and an ownership map available on the city's geoinformation website. The CommunityViz system along with the Scenario360 application were used to conduct the study. This system is an extension of the basic functionality of ArcGIS Desktop.

In accordance with article 17 of the Law on Spatial Planning and Development (Journal. Laws of 2012, No. 647 with further amendments.), the next step after preparing the draft local plan together 
with the assessment of its environmental impact is to estimate the financial consequences of passing the plan. The commune is obliged to buy the land required for a public purpose, e.g., a public road. Thus, the first information needed to estimate the liabilities of the commune is the area occupied by roads in the local plan. This surface is not equal to the area of land required for actual acquisition. Public roads can be planned, in part, on commune land, and partly on land belonging to other persons or corporate bodies. It is, therefore, important to select only that land (owned by persons other than the commune) that is essential for the construction of public roads. An overlay of property maps on the local plan can clarify the area of land required for acquisition.

The analysis helped to determine the area of the road network on the territory encompassed by the analyzed plan at close to 48,500 square meters. Assuming that the construction of roads was to be carried out solely by the commune, the city would have to buy approximately 20,600 square meters. Thanks to planning solutions, it will only be necessary to purchase approximately 3,000 square meters for communal resource. Assuming that the price of land is $450 \mathrm{PLN} / \mathrm{m}^{2}$, the commune would be required to pay approximately 1,350,000 PLN. This is a significant reduction in commitments of about 9,270,000 PLN that Wroclaw would have to bear for the implementation of the project if all roads were to be public (Fig. 1).

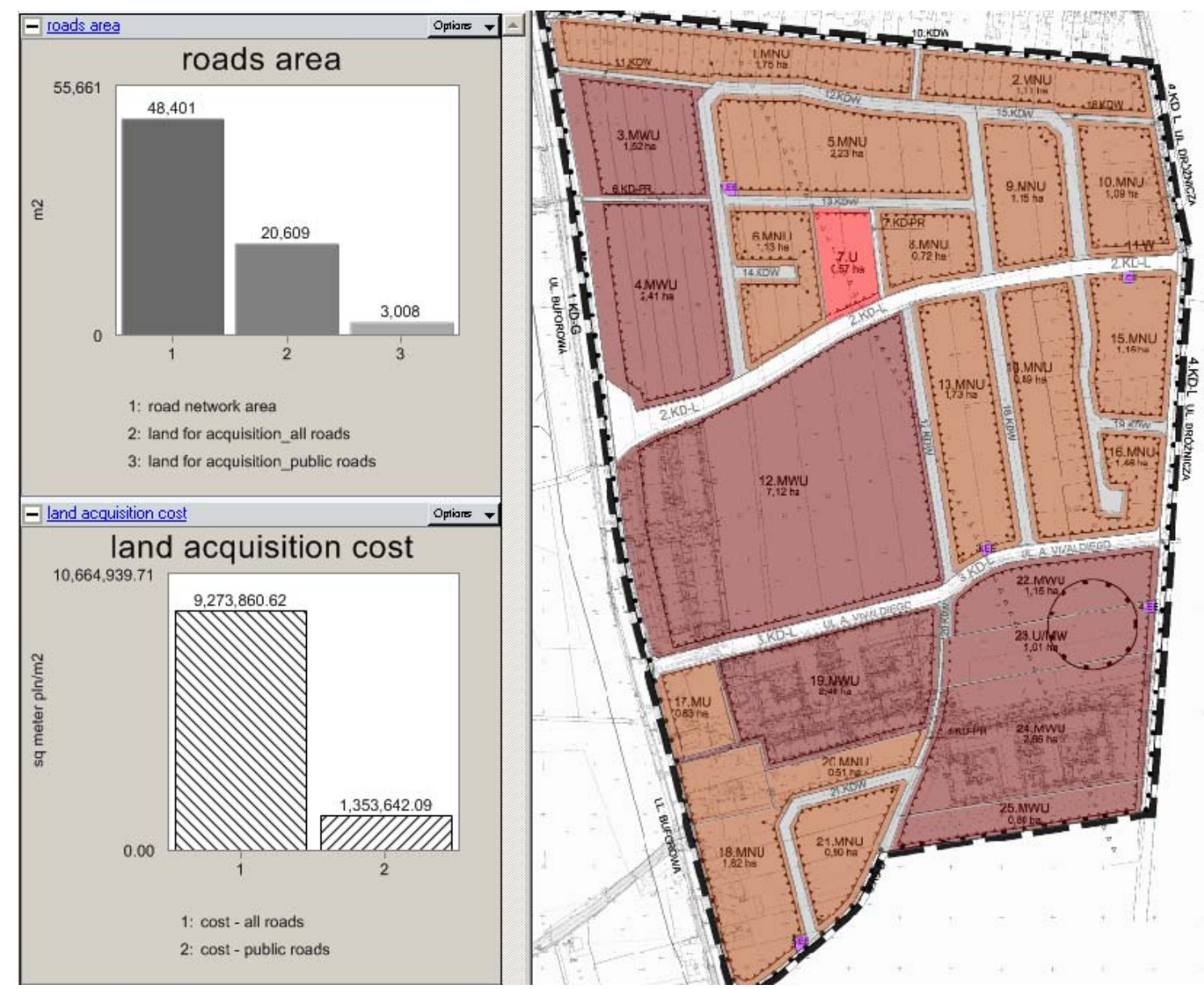

Fig. 1. Analysis of surface roads in the local plan and the resulting cost of land acquisition, Source: own study.

The analyzed local plan defines only two roads as public purpose. Most of the communication system was planned as internal roads. This course of action allows communes to significantly reduce the cost of development. On the other hand, it has an unfavorable affect on the development of the transportation system. The time at which the road infrastructure will be built is unknown and sometimes, there is a lack of access roads even after the construction of buildings. Additionally, these types of roads tend to be ultimately separated from the public transport system by barriers. In some cases, this leads to the creation of fenced in building settlements which are inappropriate because of 
social issues.

All in all, the procedure of using internal roads in local plans in order to cut costs negatively affects transport accessibility, and the roads are often not built according to building regulations (HEŁDAK et al. 2012). Minimizing land for public purposes and transferring the obligation of constructing roads onto the investor results in spontaneously emerging, ineffective communication systems. Generally speaking, such projects are also much more expensive than if they were to be well-coordinated and well-planned out (OLBRYSZ and KOZIŃSKI 2011).

\section{The decision-making process in real estate management}

Article 17 of the Law on Spatial Planning and Development (Journal. Laws of 2012, No. 647 with further amendments) does not mention the financial statement when changes are made in the record of local plans on the basis of submitted applications. The part of the process of passing the plan in which the financial consequences are forecasted is not present at the time that decisions regarding location are made and takes place afterwards. The conclusion, therefore, is that the decision-makers are not aware of its economic impact. The question remains of whether the functionality of the software used to estimate the cost of land purchase for roads can be used not only to evaluate the planning records, but also in the decision-making process. After all, it is necessary that it be possible to make such an assessment on presentation of the project, and for the presentation to clearly show the differences between the different land-use scenarios.

In order to control the potential use of data in the decision-making process, some changes were made to the local plan. They helped analyze the different aspects of land acquisition. Calculations allow all of the assumptions to be modified, and this is the main contribution of the work of a property appraiser in the functioning of this tool and the key element of the conducted analysis. Determining the value of the unit allows for a quick analysis of the cumulative value of the land. The model automatically reacts to changes in the assumptions in the control panel, updating the values of the resulting calculations and presenting them graphically. For purposes of the research, the unit value of 1 square meter was set at 450 PLN (Fig. 2). In this case, the unit value was given as an example, whereas in realty, it should be determined by a property appraiser.

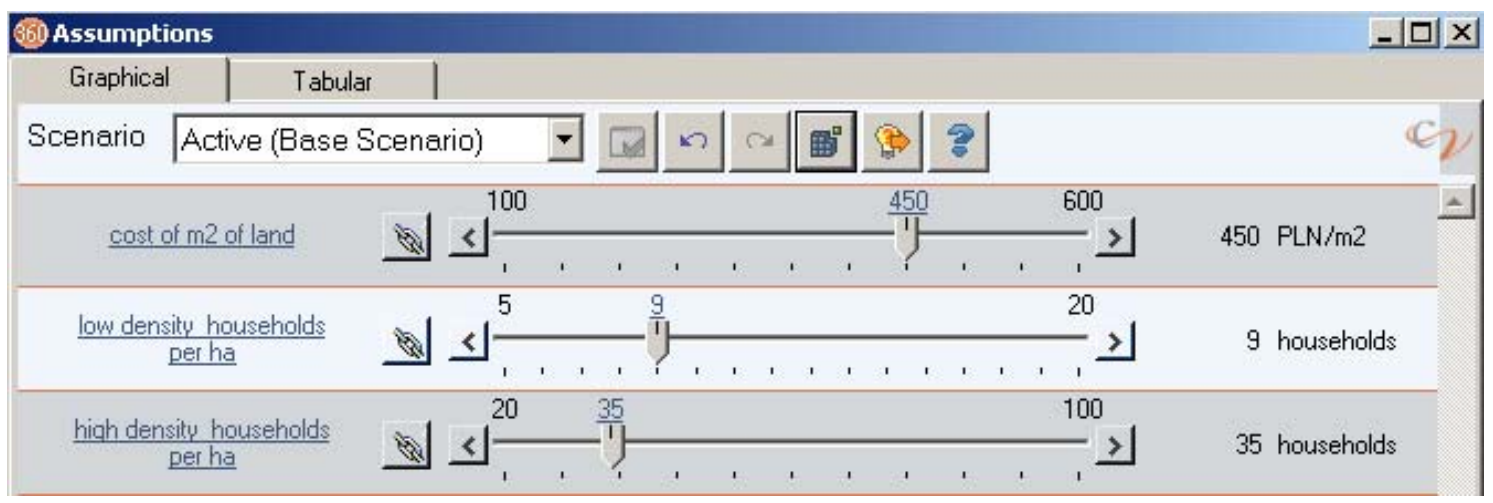

Fig. 2. Control panel showing the values of the assumptions made in the calculations, Source: own study.

The CommunityViz system is able to calculate and visualize any value that the user is able to define in a mathematical way and create a formula for the given index. The proportions of public roads to private roads defined in the local plan serve as an example of such an index. An interesting option is to analyze the cost of land acquisition for public roads in relation to the amount of households that will move in to the analyzed area as a result of the plan. The number of households is estimated based on the housing density established in the local plan. Land acquisition cost per household may reflect the efficiency and rationality of planning decisions (Fig. 3). These values may also indicate the relationship between the outlays and future income, such as a portion of the income tax collected by the commune.

\section{Summary and conclusions}

Land acquisition for road developments is an important issue, both for economic reasons (generating a financial burden on public budgets) as well as social ones (depriving owners of their 
property). In light of a changing and developing land administration system to one planning for needs and spatial integration based on a comprehensively managed information society (Zrobek and Zrobek 2008), the issue of land acquisition gains a new dimension. It is worth considering how the available spatial data and software can be taken advantage of to solve practical problems. The study indicated that in the case of specifically identified assumptions of property value (based on the knowledge of a property appraiser), geo data and their analysis can effectively support the work of a property appraiser (e.g., in the valuation of large area with different property situations on each plot). Geoinformation may, for example, be useful in forecasting the financial impact of passing a given local plan. Depending on the challenges and tasks facing those whose administer real estate, solutions presented in this paper can be applied in a number of works and to solve problematic issues. The obtained results allow us to conclude that, with the proper determination of value by the property appraiser, assumptions used in the calculations, i.e., the unit value of the property reduced to the surface area, can be effectively supported in the implementation of the forecast of the economic impact of spatial decisions.

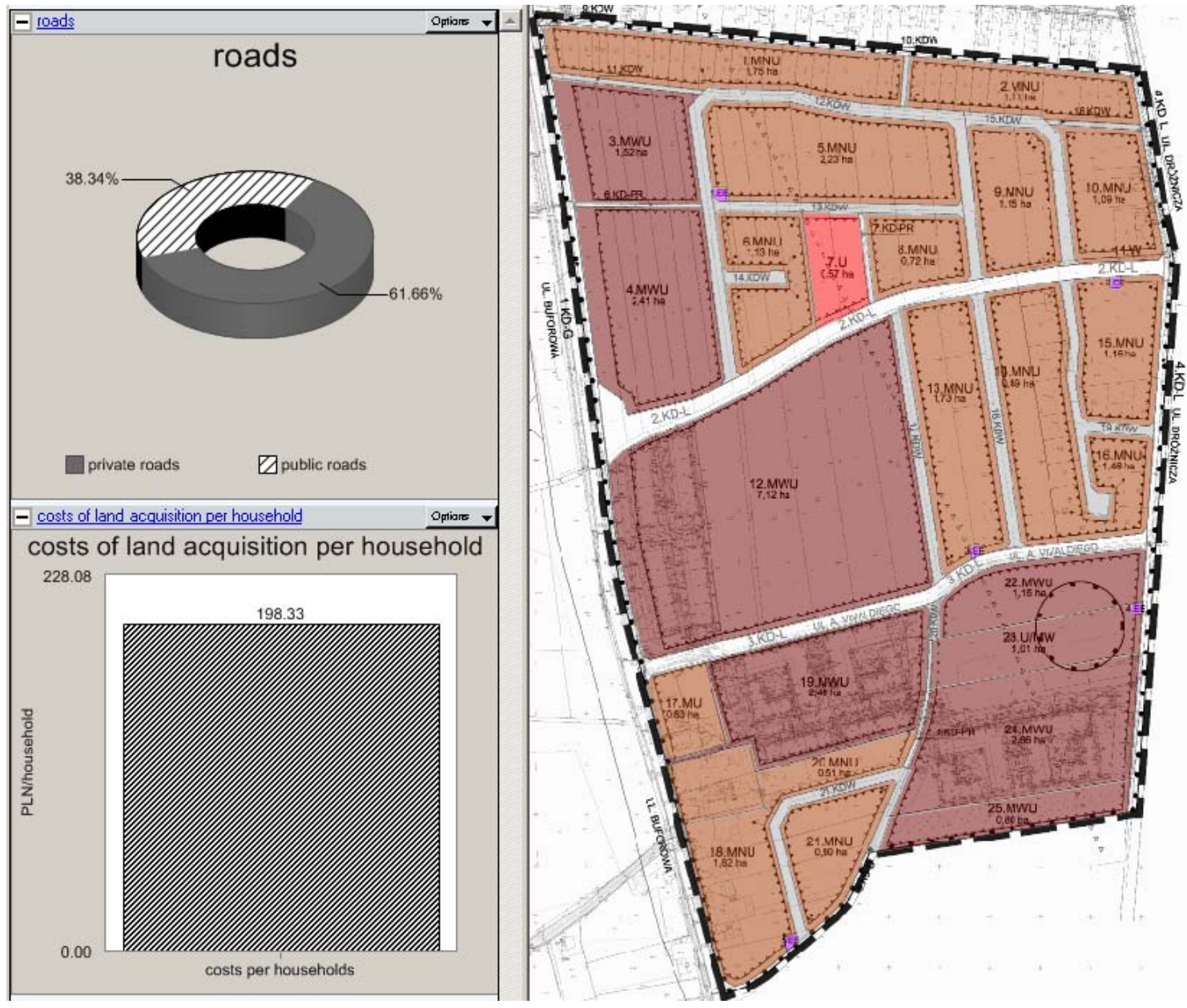

Fig. 3. Analysis of the ratio between public roads to private roads and costs of land acquisition for public roads per household, Source: own study.

In addition to helping solve problems with valuation, land administration systems based on geospatial data can provide a platform for reaching an agreement with the public. Through the clear and readable presentation of results, they can also be an instrument of public consultation, show the effects of decisions and persuade stakeholders to select different planning solutions. Public consultations can, thus, take on a new form because the focus can be moved from emotions to more objective arguments which are possible to quantify, such as the value of the properties at hand, and the cost of purchasing and developing them as intended.

The next step in research should be to determine the real estate market demand for tasks that can be accomplished with the aid of property management systems based on geoinformation. The 
standardization of such tasks may facilitate the work of public authorities at different levels, which in turn can lead to reducing the costs of their operations. The availability of systems and clarity of their operations may also have a positive impact on society, promoting participation in the decision-making process regarding issues of space, based on properties.

The study was carried out in the framework of research project NCN No. N N305 384838 "Indicator-based assessment of environmental changes caused by unsustainable sprawl of large cities."

\section{References}

DALE P., 2000, The importance of land administration in the development of land markets - a global perspective [w:] Land Markets and Land Consolidation in Central Europe, Delft.

HEŁDAK M., STACHERZAK A., KAZAK J., 2012, Zobowiazania gminy wynikajace z planu miejscowego w zakresie budowy dróg [w:] Studia i materiały Towarzystwa Naukowego Nieruchomości vol. 20, nr 4, Olsztyn.

KLERKx L., Proctor A., 2013, Beyond fragmentation and disconnect: Networks for knowledge exchange in the English land management advisory system [w:] Land Use Policy vol. 30,p.13-24.

OlBRYSZ A., KOZIŃSKI J., 2011, Raport o finansowych efektach polskiego systemu gospodarowania przestrzenia, Piaseczno.

SIKORA A., 2012, Vademecum prawne geodety, Gall, Katowice.

STEUdleR D., RAJABIFARD A., WiLliAMSO I., 2004, Evaluation of land Administration Systems [w:] Journal for Land Use Policy vol. 21, issue 4, p. 371-380.

SZABAT-PRECIKOWSKA A., 2012, Problematyka wywtaszczeń pod inwestycje liniowe [w:] Studia i materiaty Towarzystwa Naukowego Nieruchomości vol. 20, nr 4, Olsztyn.

Uchwała Nr XII/263/07 Rady Miejskiej Wrocławia z dnia 13 września 2007 r. w prawie uchwalenia miejscowego planu zagospodarowania przestrzennego obszaru Jagodno II we Wrocławiu.

Ustawa z dnia 4 marca 2010 r. o infrastrukturze informacji przestrzennej (tj. Dz. U. z 2010 r. Nr 76, poz. 489 ze zm.).

UN-ECE, 1996, Land Administration Guidelines with Special Reference to Countries in Transition, New Your, Geneva.

UN-ECE, 2005, Land Administration in the UNECE Region, Development trends and main principles, New Your, Geneva.

WĘŻYK P., WAŃCZYK R., 2008, Implementacja dyrektywy INSPIRE na przykładzie internetowego serwisu "Mapa roślinności rzeczywistej miasta Krakowa” [w:] Archiwum Fotogrametrii, Kartografii i Teledetekcji vol. 18, Kraków.

ŹRÓBEK S., WALACIK M., 2008, Problematyka nabywania gruntów pod budowę dróg [w:] Studia i materiaty Towarzystwa Naukowego Nieruchomości vol. 16, nr 1, Olsztyn.

ŹRÓBEK S., ŹRÓBEK R., 2008, Wybrane aspekty doskonalenia systemów gospodarowania zasobami nieruchomości [w:] Studia i materiaty Towarzystwa Naukowego Nieruchomości vol. 16, nr 1, Olsztyn.

ŹRÓBEK S., ŹRÓBEK R., KURYJ J., 2012, Gospodarka nieruchomościami z komentarzem do wybranych procedur, Gall, Katowice. 